ENTREPRENEURSHIP AND SUSTAINABILITY ISSUES

ISSN 2345-0282 (online) http://jssidoi.org/jesi/

2020 Volume 7 Number 4 (June)

http://doi.org/10.9770/jesi.2020.7.4(52)

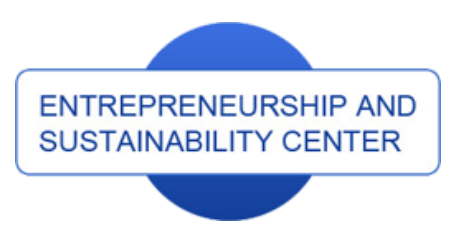

Publisher

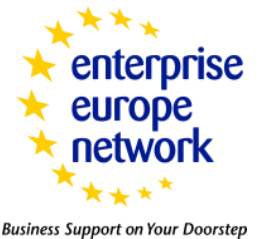

CASPA
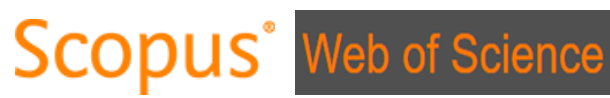

http://jssidoi.org/esc/home

I Clarivate

Analytics

\title{
CONCENTRATION OF OIL SECTOR OR DIVERSIFICATION IN SAUDI ECONOMY: CONSEQUENCES ON GROWTH SUSTAINABILITY*
}

\section{Khalid Abdullah Alkhathlan ${ }^{1}$, Tarek Tawfik Yousef Alkhateeb ${ }^{2}$, Haider Mahmood ${ }^{3}$, Wardah Abdulrahman Bindabel ${ }^{4}$}

\author{
${ }^{1}$ Economics Department, King Saud University, Saudi Arabia

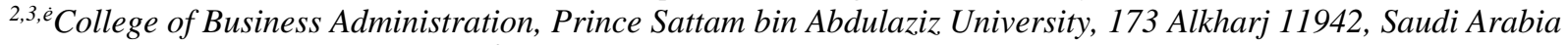 \\ ${ }^{2}$ Kafr Elshiekh University, Kafr Elshiekh 33511, Egypt

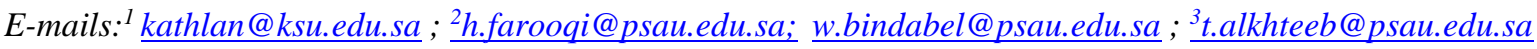

Received 10 February 2020; accepted 25 May 2020; published 30 June 2020

\begin{abstract}
Oil sector contributes most of macroeconomic performance in Saudi Arabia. Using a period 1970-2018, we calculate the production, exports, government revenues, investment and employment concentration indices using normalized Herfindahl Hirschman index and test the effects of concentration indices on the economic growth. We find that exports and government revenues are highly concentrated and majorly depend on the oil sector. Employment is more concentrated by public sector and production is majorly concentrated on oil sector. Investment is shown relatively lesser dependence on the oil sector with compare to exports, production and government revenues. In the long run, we find the positive effects of production and government revenue concentrations on the economic growth and negative effects of exports and employment concentrations. Moreover, we find the Granger causality from production concentration to the economic growth, from government revenue and exports concentrations to the production concentration, from investment concentration to the export concentration and from production, investment and government revenue concentrations to the employment concentration.
\end{abstract}

Keywords: oil sector; concentration and diversification; economic growth; government revenues; investment; exports

Reference to this paper should be made as follows: Alkhathlan, K.A., Alkhateeb, T.T.Y., Mahmood, H., Bindabel, W.A. 2020. Concentration of oil sector or diversification in Saudi economy: consequences on growth sustainability. Entrepreneurship and Sustainability Issues, 7(4), 3369-3384. http://doi.org/10.9770/jesi.2020.7.4(52)

JEL Classifications: O13, O11, L25, F14

\footnotetext{
* The authors extend their appreciation to the Deputyship for Research \& Innovation, Ministry of Education in Saudi Arabia for funding this research work through the project number (DRI-KSU-SS-341).
} 


\section{ENTREPRENEURSHIP AND SUSTAINABILITY ISSUES}

ISSN 2345-0282 (online) http://jssidoi.org/jesi/

2020 Volume 7 Number 4 (June)

http://doi.org/10.9770/jesi.2020.7.4(52)

\section{Introduction}

Saudi Arabia is an oil rich economy and depends heavily on the oil sector in her income, exports and government revenue. Economic diversification may be initiated by a gradual process to diversify the source of income from oil sector to the other sectors like increasing contribution of industrial and service sectors in the income. Saudi government has targeted the diversification from oil sector in her all development plans since 1970. But, Saudi Arabia could not be achieved acceptable diversification compared to other rentier countries (Merzuk 2013). Moreover, the government of Saudi Arabia is also planning for economic diversification in the long term Vision 2030. Economic diversification from oil sector is an urgent need of Saudi economy due to its heavy reliance on this sector. The fluctuations and low level of oil prices in the world market now-a-day might be considered as a threat to the maroeconomic sustainability of the economy. Government of Saudi Arabia has been targeted the diversification policy in the most of 5-years development plans and have reduced some of oil dependence as well. For example, the contribution of the oil sector in Gross Domestic Product (GDP) fell from 58.5\% during the first development plan of 1970-74 to 28.6\% during a period of 2015-2018 in tenth development plan (Saudi Arabian Monetary Agency 2019).

Table 1 shows 5-years average contributions of oil sector in the exports, government revenue, investment and production during the ten development plans from 1970-2018. The contribution of oil sector in GDP was observed highest during the first development plan 1970-74 and it gradually decreased to $25.5 \%$ till the fourth development plan 1985-89. Afterwards, it showed mostly increasing trend till eighth development plan 2005-09 and fell afterwards. In the last period $2015-18$, the proportion $28.6 \%$ is found least with compare to all development plans except 1985-89. This sharp decline in proportion of oil sector in GDP may be claimed due to an achievement of government policy toward diversification and may also be due to global oil price crisis. In the non-oil sector profile, the private sector contribution has gradually been increased from $28 \%$ during the first development plan 1970-74 to 50.4\% during fourth development plan 1985-89. Then, it gradually decreased till the eighth development plan 2005-09 and has positive trend afterwards. The non-oil private sector contribution to GDP has showed an opposite trend to the trend of oil sector contribution in the all development plans. In the same line, non-oil government sector share in GDP has also the opposite trend to the trend of oil sector in most of development plans. Therefore, both private and public sectors are proved to be helpful in diversification process of conversion from oil to non-oil sector in the Kingdom.

In the fiscal domain, the oil sector contribution to government revenue has showed a high dependence in the first development plan 1970-74 but it declined gradually from $90.6 \%$ during first development plan to $62 \%$ in the fourth development plan 1985-89. Afterwards, it picked a continues positive trend till ninth development plan 2010-14 and stood at same position of first development plan 1970-74 but decreased tremendously in the last development plan during 2015-18. In the exports' market, oil exports contributed about $100 \%$ of total exports in the first two development plans during 1970-79 and contributed 98.4\% in the third development plan 1980-84. In the fourth development plan 1985-89, a sharp decline was observed and contribution of oil exports was observed around $90 \%$ in total exports in the development plans during 1985-2009 with the minute fluctuations. Afterwards, a declining trend has been observed in the last two development plans during 2010-18.

Investment in the oil sector was $25.4 \%$ of total investment in the first development plan 1970-74 which was highest compared to other development plans. Then, it gradually decreased till fifth development plan and was observed at 7.2\% during 1990-94. Afterwards, it showed a mix of increasing and decreasing trends during 19952018. The most proportion of investment was from non-oil private sector during 1985-2018 and the public sector investment share has been found largest during 1970-1984 which tremendously fell during 1995-2004. The oil sector employment data could not be found for sample period so we discuss the employment in the private and public sectors. Private sector shows more employment share than the public sector in the all development plans 


\section{ENTREPRENEURSHIP AND SUSTAINABILITY ISSUES}

ISSN 2345-0282 (online) http://jssidoi.org/jesi/

2020 Volume 7 Number 4 (June)

http://doi.org/10.9770/jesi.2020.7.4(52)

and has also showed an increasing trend in most of development plans during 1970-2018. The public sector employment share was found significant in the first six development plans but it declined sharply in the seventh development plan.

Table 1. Evolution of economic diversification or concentration indicators during economic development plans

\begin{tabular}{|c|c|c|c|c|c|c|c|c|c|c|c|c|}
\hline \multirow{2}{*}{$\begin{array}{l}\text { Development } \\
\text { Plan }\end{array}$} & \multicolumn{3}{|c|}{ GDP Share (\%) } & \multicolumn{2}{|c|}{$\begin{array}{c}\text { Exports Share } \\
(\%)\end{array}$} & \multicolumn{2}{|c|}{$\begin{array}{c}\text { Govt. Revenue } \\
\text { Share }(\%)\end{array}$} & \multicolumn{3}{|c|}{ Investment Share $(\%)$} & \multicolumn{2}{|c|}{ Employment } \\
\hline & Oil & Private & Govt. & Oil & $\begin{array}{c}\text { Non- } \\
\text { oil }\end{array}$ & Oil & Non-oil & Oil & Private & Govt. & Private & Govt \\
\hline $1970-74$ & 58.5 & 28 & 13.5 & 99.5 & 0.5 & 90.6 & 9.4 & 25.4 & 34.4 & 40.2 & 61 & 39 \\
\hline $1975-79$ & 56.9 & 34.4 & 8.7 & 99.7 & 0.3 & 88.8 & 11.2 & 13.2 & 28.1 & 58.7 & 66.6 & 33.4 \\
\hline 1980-84 & 48.7 & 38.3 & 13 & 98.4 & 1.6 & 79.5 & 20.5 & 11 & 33.6 & 55.4 & 74.6 & 25.4 \\
\hline $1985-89$ & 25.5 & 50.4 & 24.1 & 87.9 & 12.1 & 62 & 38 & 7.9 & 50.3 & 41.8 & 63.2 & 36.8 \\
\hline $1990-94$ & 36.4 & 40.7 & 22.9 & 91 & 9 & 75.5 & 24.5 & 7.2 & 52.3 & 40.5 & 64.5 & 35.5 \\
\hline 1995-99 & 34.7 & 41.8 & 23.5 & 87.3 & 12.7 & 70.7 & 29.3 & 10.8 & 74 & 15.2 & 71 & 29 \\
\hline $2000-04$ & 40 & 39.3 & 20.7 & 88.7 & 11.3 & 80.9 & 19.1 & 11.2 & 74.2 & 14.6 & 89.5 & 10.5 \\
\hline 2005-09 & 49.5 & 34.7 & 15.8 & 88.2 & 11.8 & 88.2 & 11.8 & 14.1 & 62.3 & 23.6 & 87.5 & 12.5 \\
\hline 2010-14 & 47 & 37.2 & 15.8 & 85.7 & 14.3 & 90.5 & 9.5 & 11.1 & 51.6 & 37.3 & 88.6 & 11.4 \\
\hline 2015-18 & 28.6 & 48.6 & 22.8 & 76.2 & 23.8 & 66.9 & 33.1 & 13.7 & 55.9 & 30.4 & 89.9 & 10.1 \\
\hline
\end{tabular}

In summing up, Saudi Arabia is heavily depending on the oil-sector in terms of income, exports and government revenue. The economy has targeted the diversification policy in all 5-years development plans since 1970, but still the diversification level is lesser than the projected level (Al Bakr 2015). Particularly, government revenue and exports are still heavily relying on the oil sector. Before targeting any diversification policy, it is very pertinent to test the effects of income, exports, investment, employment and government revenue diversifications on the economic growth sustainability because the major objective of any economic policy is a sustainable growth. Some studies have been investigated the effects of income diversification on the economic growth of Saudi Arabia with the mix evidences of findings (Al-Tit and Omri 2018; Al-Khatib 2011; Al-Khatib 2014). But, Saudi literature is still silent to test the effects of exports, investment and government revenue diversifications on the economic growth by estimating the concentration indices of these macroeconomic indicators. So, this present study is intended to find major types of macroeconomic diversifications using normalized Herfindahl Hirschman index and tests their effects on the economic growth of Saudi Arabia using a maximum available range of data (raw data is provided in appendix).

\section{Literature Review}

Economic diversification from oil sector may be assumed a process to reduce the contribution of the oil sector in government revenues, exports, investment and GDP of oil-dependent economies. In general, economic diversification aims to: (1) expand the opportunities and prospects for domestic and foreign direct investment and increase commercial partners and international markets, (2) strengthen ties between economic sectors and thus achieve economic stability, (3) expand and diversify the value added from maximum economic sectors (4) providing opportunities for national employment, and (5) creating the exports substitution industry that contributes to strengthening the forward and backward linkages of existing industries.

The diversification policy may activate the low contributing sectors of an economy to be worked at full potential to contribute in the income and economic growth of the country. In this regard, the testing of the impact of diversification on the economic growth seems important. Literature is available with the studies of economic diversification and its impact on growth and development of the countries. For example, Ghanem and Fawaz (1998) studied the factors determining the allocation of economic and agricultural resources in light of the 


\section{ENTREPRENEURSHIP AND SUSTAINABILITY ISSUES}

ISSN 2345-0282 (online) http://jssidoi.org/jesi/

2020 Volume 7 Number 4 (June)

http://doi.org/10.9770/jesi.2020.7.4(52)

targeted structural change in the Egyptian economy. The study indicated that the structural change occurred in the Egyptian economy but could not support to the growth and development. It gave push to the sectors which showed less productivity during the period 1976-1997. Other than economic growth, the role of economic diversification has been tested on the other different macroeconomic performance indicators in the literature. For example, del Rosal (2019) investigated the role of export diversification using Herfindahl index on the exportperformance. In contrast, he found that exports' concentration helped in raising export-performance. Ali and Memon (2019) examined the effect of exports' diversification on the human development in the South Asia. They assumed different proxies of exports' diversification and found the positive effect of each proxy on the human development. Cai et al. (2018) explored the role of diversified exploitation and exploration on innovate policy logics and found the positive role in case of Finland and Norway. Nisar et al. (2018) studied the effects of income diversification on the technical and scale efficiencies of the commercial banks of South Asia. They reported that income diversification showed the significant and positive effects on the all types of efficiencies of the banks in the South Asia. Basile et al. (2018) investigated the relationship between exports' diversification and economic development of 114 countries in a sample period 1992-2012, considering the spatial effects. They found the spatial dependence in the exports diversification model through spillovers. Particularly, large countries showed larger diversification effects.

The economic diversification has also been found helpful to reduce the cyclical effects in the times of the crises of the economies. Ji and Mei (2019) inspected the performance of exports' diversification on the fiscal pro-cyclical movements. They found that export's diversification helped in reducing the fiscal pro-cyclical movements. Liu et al. (2018) investigated the role of industrial and global diversification of US firms on the economic downturns/crises. They found that both kinds of diversifications supported the firms to be stabilized in the economic downturn periods through increasing investments and through products' performance of the diversified industries. Adelaja and Akaeze (2018) examined the influence of diversification from oil, oil reserves and exchange rate on the recovery from oil price crisis of 53 oil-producing countries. They found that with an increase in oil price after crisis period, diversification accelerated the economic recovery. Alley (2018) reconnoitered the support of export diversification on the exchange rate crash of Naira. He found that oil price crash of 2014 directly depreciated the Naira significantly which could not be improved after many government policies and initiatives. But, increase in non-oil exports and revenues helped to appreciate the Naira and to be stabilized in the international market. Masood et al. (2019) estimated impact of oil prices on stock return of G7 countries.

There are a number of studies investigating the issue of economic diversification in the context of Saudi Arabia. In the descriptive analyses, Albassam (2015) utilized the percentage contribution of oil sector to GDP, to government revenues, to total exports of Saudi Arabia during 1970-2013. He argued that this economy could not achieve the targeted diversification. After the oil price crisis of 2014, Al Bakr (2015) discussed the need of production-based diversification from the oil sector in the Kingdom of Saudi Arabia in his descriptive analyses. He argued that Saudi Arabia had targeted the diversification policy in each of her five year plans since 1970 but still diversification was found lesser than the targeted expectations. He discussed the demand sided and supply sided issues of diversification policy and suggested that Small and Medium Enterprises (SMEs) with government support might play a significant role in diversification process. He confronted that SMEs were only focusing on the low value-added activities like trade and construction. The foreign investors were also focusing the construction sector majorly. Further, labor was also remitting most of their income to their mother countries which could not benefit the local economy. He recommended the government to divert the FDI and SMEs activities towards high value-added activities to raise productivity and to accelerate the process of diversification.

Jawadi and Ftiti (2019) investigated the relationship between oil-dependency and economic growth of Saudi Arabia. They found the positive effect of oil sector production on the economic growth in the nonlinear settings. Further, the effect of oil price was found different at different oil market conditions (booms or busts) and equity investment played the pleasant effects on the economic growth. Moreover, they favored the diversification policy 
ENTREPRENEURSHIP AND SUSTAINABILITY ISSUES

ISSN 2345-0282 (online) http://jssidoi.org/jesi/

2020 Volume 7 Number 4 (June)

http://doi.org/10.9770/jesi.2020.7.4(52)

according to the Vision 2030. Aker and Aghaei (2019) examined the effects of exports 'diversification and economic performance on the business competitiveness of 11 oil-rich countries, including Saudi Arabia. They found that both exports' diversification and economic performance played the important role in raising business competitiveness. Maalel and Mahmood (2018) investigated the role of oil-income and oil-exports dependency on the economic growth of GCC countries including Saudi Arabia in the asymmetric settings. They find that oilincome has insignificant effect on the economic growth of Saudi Arabia. Further, oil-exports dependency has negative effects on the economic growth with asymmetric magnitude of effects. Both increasing and decreasing oil-exports dependency had negative relationship with the economic growth of the Saudi Arabia but increasing oil-exports dependency had relatively greater negative effects on the economic growth than that of decreasing oilexports dependency.

Al-Khatib (2011) investigated the role of diversification on the economic growth using a period 1970-2008. He found the positive effect of diversification on the economic growth. Al-Khatib (2014) re-investigated the effect of diversification on economic growth in the Saudi economy during the period 1970-2011. They found that the goal of diversifying could not be achieved as a production-based economy as oil exports majorly contributed the total exports and also contributed the major government revenues as well. Further, he found the insignificant effects of diversification on the economic growth. On the other hand, Al-Tit and Omri (2018) found that economic diversification positively contributed in the job creation, improving the institutional quality and promoting the economic growth of Saudi Arabia. They also found that oil price and trade also contributed in the economic growth.

The literature signifies the importance of economic diversification on the economic growth and on the other macroeconomic performance. The role of production diversification from oil sector has also been tested on the economic growth in case of Saudi Arabia. But, Saudi literature is still silent to investigate the role of exports, government revenue, investment and employment diversifications on the economic growth and this present is highly motivated to fill this literature gap.

\section{Methods}

First objective of this research is to calculate the diversification indices for production, government revenue, exports, investment and employment in Saudi Arabia. Hirschman (1964) proposed an index to measure the competition or concentration in the industry. Further, United Nations Trade and Development Organization (UNCTAD) utilized a Normalized Herfindahl Hirschman Index (HHI) to measure the exports concentration. Following UNCTAD and Lapteacru (2012), the normalized HHI is as follows:

$H=\left[\sum_{1}^{N}\left(\frac{x_{i}}{X}\right)^{2}-\frac{1}{N}\right] /\left[1-\frac{1}{N}\right]$

Where, $x_{i}$ is value of one sector exports and $X$ is total value of exports. $H$ is an indicator of exports' concentration normalized by number of types of exports $(N)$. The value of the $H$ coefficient ranges from zero to one. Zero represents the perfect diversification in export sector and one represents the perfect concentration on one sector exports. Saudi economy is mostly depending on the oil for exports performance. Therefore, the increasing value of $H$ may represent the oil exports' concentration and decreasing value of $H$ represents the diversification from oil exports. In the same way, the $H$ index will be estimated to calculate the concentration of oil production in the total production, government revenue from oil sector in the total government revenue, investment in oil sector to total 
investment and employment concentration in the Saudi Arabia. In all, increasing trend of $H$ shows the increasing concentration and decreasing trend of $H$ shows the increasing diversification.

After estimating the level of concentration or diversification, we test the effects of all calculated concentration variables on the economic growth through regression analyses. Further, we also aim to find the causality among the hypothesized variables of the model to test the direction of relationships. Before moving to regressions or causality analyses, we test the unit root problem in all the focused series using Dickey and Fuller (1981) methodology as follows:

$$
\begin{aligned}
& \Delta x_{t}=\beta x_{t-1}+\sum_{i=1}^{k} \vartheta_{i} \Delta x_{t-i}+\xi_{t} \\
& \Delta x_{t}=\alpha+\beta x_{t-1}+\sum_{i=1}^{k} \vartheta_{i} \Delta x_{t-i}+\xi_{t} \\
& \Delta x_{t}=\alpha+\lambda t+\beta x_{t-1}+\sum_{i=1}^{k} \vartheta_{i} \Delta x_{t-i}+\xi_{t}
\end{aligned}
$$

In equation 2, null hypothesis of unit root in the series $x_{t}(\beta=0)$ is tested assuming no intercept and no trend in the series and rejection of it would be an evidence of stationary series. Same procedure would be applied assuming intercept in the series in equation 3 and assuming both intercept and trend in the series in equation 4 . After unit root analyses, we move towards Autoregressive Distributive Lag (ARDL) cointegration technique proposed by Pesaran et al. (2001). This technique is chosen due to its superiority on the other techniques. For example, it removes the endogeneity problem in the model by autoregressive process. Secondly, it provides efficient results in the presence of a mix order of integration. A mix order of integration may be expected in the model as some of the economic variables may be found stationary at their level and others on their first differences. Our objective is to test the effects of all concentration or diversification macroeconomic indicators on the economic growth and is also to test the causal relationships among the diversification proxies and economic growth. To test the causality, we need to test the cointegration among the variables assuming all variables as dependent variables one by one in the analyses. For this purpose, a system of ARDL equations is as follows:

$$
\begin{aligned}
& {\left[\begin{array}{l}
\Delta G D P C_{t} \\
\Delta P D_{t} \\
\Delta R D_{t} \\
\Delta E X D_{t} \\
\Delta I D_{t} \\
\Delta E M D_{t t}
\end{array}\right]=\left[\begin{array}{l}
\delta_{01} \\
\delta_{02} \\
\delta_{03} \\
\delta_{04} \\
\delta_{05} \\
\delta_{06}
\end{array}\right]+\left[\begin{array}{l}
\delta_{11} \delta_{12} \delta_{13} \delta_{14} \delta_{15} \delta_{16} \\
\delta_{21} \delta_{22} \delta_{23} \delta_{24} \delta_{25} \delta_{26} \\
\delta_{31} \delta_{32} \delta_{33} \delta_{34} \delta_{35} \delta_{36} \\
\delta_{41} \delta_{42} \delta_{43} \delta_{44} \delta_{45} \delta_{46} \\
\delta_{51} \delta_{52} \delta_{53} \delta_{54} \delta_{55} \delta_{56} \\
\delta_{61} \delta_{62} \delta_{63} \delta_{64} \delta_{65} \delta_{66}
\end{array}\right] *\left[\begin{array}{l}
G D P C_{t-1} \\
P D_{t-1} \\
R D_{t-1} \\
E X D_{t-1} \\
I D_{t-1} \\
E M D_{t-1}
\end{array}\right]+\sum_{i=1}^{p}\left[\begin{array}{l}
\varphi_{1 i} \\
\varphi_{3 i} \\
\varphi_{4 i} \\
\varphi_{5 i} \\
\varphi_{6 i}
\end{array}\right] *\left[\begin{array}{l}
\Delta G D P C_{t-i} \\
\Delta P D_{t-i} \\
\Delta R D_{t-i} \\
\Delta E X D_{t-i} \\
\Delta I D_{t-i} \\
\Delta E M D_{t-i}
\end{array}\right]} \\
& +\sum_{i=0}^{p}\left[\begin{array}{l}
0 \phi_{11 i} \phi_{12 i} \phi_{13 i} \phi_{14 i} \phi_{15 i} \\
\phi_{21 i} 0 \phi_{22 i} \phi_{23 i} \phi_{24 i} \phi_{25 i} \\
\phi_{31 i} \phi_{32 i} 0 \phi_{33 i} \phi_{34 i} \phi_{35 i} \\
\phi_{41 i} \phi_{42 i} \phi_{43 i} 0 \phi_{44 i} \phi_{45 i} \\
\phi_{51 i} \phi_{52 i} \phi_{53 i} \phi_{54 i} 0 \phi_{55 i} \\
\phi_{61 i} \phi_{62 i} \phi_{63 i} \phi_{64 i} \phi_{65 i} 0
\end{array}\right] *\left[\begin{array}{l}
\Delta G P C_{t-i} \\
\Delta P D_{t-i} \\
\Delta R D_{t-i} \\
\Delta E X D_{t-i} \\
\Delta I D_{t-i} \\
\Delta E M D_{t-i}
\end{array}\right]+\left[\begin{array}{l}
\psi_{1 t} \\
\psi_{2 t} \\
\psi_{3 t} \\
\psi_{4 t} \\
\psi_{5 t} \\
\psi_{6 t}
\end{array}\right]
\end{aligned}
$$


Here, $G D P C_{t}$ is GDP per capita in constant Saudi Riyal. $P D_{t}, R D_{t}, E X D_{t}, I D_{t}$, and $E M D_{t}$ are the $H$ indices estimated through equation 1 to calculate the production concentration, government revenue concentration, exports concentration, investment concentration and employment concentration respectively. All variables are taken in natural logarithm form to estimate the elasticity coefficients. The data on GDP per capita and data to estimate all $H$ indices are sourced from Saudi Arabian Monetary Agency (2019).

The equation 5 would be tested for the cointegration by Bound test procedure of Peasarn et al. (2001) after selection of optimum lag length by Schwarz Information Criteria (SIC) in the system of equations. Null hypothesis of no cointegration ( $\delta_{11}=\delta_{12}=\delta_{13}=\delta_{14}=\delta_{15}=\delta_{16}=0$ ) would be tested to find the cointegration in the model when $G D P C_{t}$ is dependent variable and rejection of null would corroborate the cointegration in the model. After confirmation of cointegration, we may estimate the long run effects of independent variables on the economic growth by normalizing $\delta_{12}, \delta_{13}, \delta_{14}, \delta_{15}$, and $\delta_{16}$ normalized by $\delta_{11}$. Later, short run effects can be captured with estimated $\varphi_{1 i}, \phi_{11 i}, \phi_{12 i}, \phi_{13 i}, \phi_{14 i}$, and $\phi_{15 i}$. To find the cointegration in the other equations, same procedure can be applied on the null hypotheses of $\left(\delta_{21}=\delta_{22}=\delta_{23}=\delta_{24}=\delta_{25}=\delta_{26}=0\right)$, $\left(\delta_{31}=\delta_{32}=\delta_{33}=\delta_{34}=\delta_{35}=\delta_{36}=0\right), \quad\left(\delta_{41}=\delta_{42}=\delta_{43}=\delta_{44}=\delta_{45}=\delta_{46}=0\right)$, $\left(\delta_{51}=\delta_{52}=\delta_{53}=\delta_{54}=\delta_{55}=\delta_{56}=0\right)$, and $\left(\delta_{61}=\delta_{62}=\delta_{63}=\delta_{64}=\delta_{65}=\delta_{66}=0\right)$, for the models assuming $P D_{t}, R D_{t}, E X D_{t}, I D_{t}$, and $E M D_{t}$ as dependent variables respectively. The cointegtation of these models would be attested to apply the causality analyses. Equation 6 presents a system of equations to conduct the causality analyses through Vector Error Correction Model (VECM) as follows:

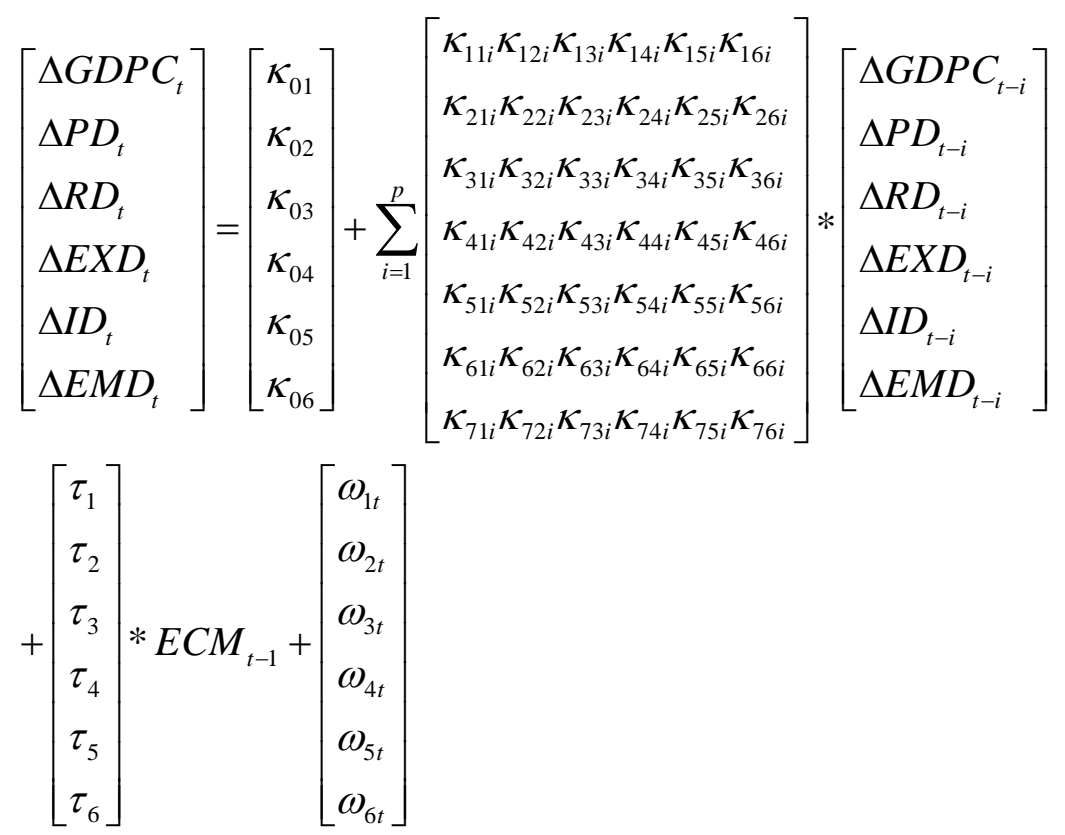

The optimum lag length could be selected through SIC in above system. The long run causality can be corroborated by the statistically significant $E C M_{t-1}$ in each single equation of the system of equations 6 . Then, we can do short causality analyses by applying the Wald test on the coefficients of lagged differenced variables in the equation with a null hypothesis of no causality. A rejection of null hypothesis would corroborate the direction of causality from one variable to the other in the above system of equations. 


\section{ENTREPRENEURSHIP AND SUSTAINABILITY ISSUES}

ISSN 2345-0282 (online) http://jssidoi.org/jesi/

2020 Volume 7 Number 4 (June)

http://doi.org/10.9770/jesi.2020.7.4(52)

\section{Data Analyses and Discussions}

Table 2 shows the concentration or diversification indices following the equation 1 . It is clear from the data presented in table 1 that the fifth and sixth development plans are less concentrated and are more most diversified plans in term of GDP, and then the seventh development plan followed by the tenth development plan are on the third and fourth position in term of production diversification. During these plan periods, government and private sectors contributed significantly in GDP as compare to other development plans. Moreover, the production index shows lowest average index during 1970-2018 with compare to other all estimated indices. So, it shows a lower level of concentration and higher level of diversification throughout the sample period 1970-2018 with compare to other concentration indices. The same story can be observed in case of investment concentration index because its index showed a lower level of concentration and higher level of diversification in most of sample period except two development plans during 1995-2004. During 1995-2004, the private sector investment proportion is found larger than the sum of oil and government sectors' contribution in total investment and is also higher than the its own proportion in the other development plans which is a good indicator for growth of non-oil sector in the economy during 1995-2004. Moreover, the investment index shows second lowest average during the sample period 1970-2018 after the lowest average of production index. As per the government revenue concentration index, fourth development plan is found most diversified followed by tenth, sixth and fifth development plans. But, these plans still carry more than $60 \%$ contribution of the oil sector in the total government revenue. Rest of development plans looks significantly concentrated on the oil sector. Particularly, first, second, eighth and ninth development plans are highly concentrated on the oil sector by carrying around $90 \%$ contribution of oil sector in the total government revenues. In the exports sector, the average of exports concentration during all the sample period is found highest among all the calculated concentration. Particularly, the oil sector concentration is found very high in the first three development plans during 1970-1984 where oil sector contributed more than $95 \%$ of total exports. Even after this period, oil sector concentration index is found very high till 2014 and oil sector contributed at least more than $85 \%$ of total exports during 1970-2014. Recently, the exports' concentration index is dramatically fallen in last development plan during 2015-18 but still oil sector is contributed more than $75 \%$ in this period. The employment index carries only public and private sectors' contribution in total employment as oil sector employment data could not be found for the sample period. HHI of employment shows a fair concentration which does mean that proportion of public sector employment is high with compare to private sector employment. Public sector employment proportion is around 35\% during 1970-1994. Afterwards, the public sector contribution decreased to $15 \%$ during $1995-2018$.

Table 2. HHI during economic development plans

\begin{tabular}{|c|c|c|c|c|c|c|}
\hline $\begin{array}{c}\text { Development } \\
\text { Plan }\end{array}$ & PD $_{\mathrm{t}}$ & EXD $_{\mathrm{t}}$ & $\mathrm{RD}_{\mathrm{t}}$ & $\mathrm{ID}_{\mathrm{t}}$ & EMD $_{\mathrm{t}}$ & Average \\
\hline $1970-74$ & 0.1887 & 0.9797 & 0.6618 & 0.0279 & 0.0482 & 0.3813 \\
\hline $1975-79$ & 0.1812 & 0.9862 & 0.6027 & 0.1676 & 0.1204 & 0.4116 \\
\hline $1980-84$ & 0.1352 & 0.9386 & 0.3825 & 0.1601 & 0.2440 & 0.3721 \\
\hline $1985-89$ & 0.0672 & 0.5813 & 0.0665 & 0.1571 & 0.0704 & 0.1885 \\
\hline $1990-94$ & 0.0270 & 0.6712 & 0.2603 & 0.2005 & 0.0851 & 0.2488 \\
\hline $1995-99$ & 0.0283 & 0.5579 & 0.1933 & 0.3905 & 0.2074 & 0.2755 \\
\hline $2000-04$ & 0.0373 & 0.5996 & 0.3849 & 0.3775 & 0.6244 & 0.4047 \\
\hline $2005-09$ & 0.0914 & 0.5861 & 0.5856 & 0.1988 & 0.5633 & 0.4050 \\
\hline $2010-14$ & 0.0789 & 0.5102 & 0.6570 & 0.1286 & 0.5956 & 0.3941 \\
\hline $2015-18$ & 0.0577 & 0.2753 & 0.1202 & 0.1397 & 0.6357 & 0.2457 \\
\hline Average & 0.0893 & 0.6686 & 0.3915 & 0.1948 & 0.3195 & 0.3327 \\
\hline
\end{tabular}

Source: Authors calculation 
After observing the concentration and diversification issues, we aim to find the relationships among economic growth and concentration indicators. For this purpose, we investigate the unit root issue in the hypothesized series and table 3 shows the unit root test results. It can be observed that all the variables are non-stationary at levels except $\mathrm{RD}_{\mathrm{t}}$ and $\mathrm{EXD}_{\mathrm{t}}$ which show the stationary behavior in some of the tested unit root equations. On their first differences, all variables are stationary at $1 \%$ level of significance. Unit root test shows a mix order of integration due to some evidences of stationary leveled variables. But, ARDL cointegration gives consistent results in this situation due to Bound testing procedure (Pesaran et al. 2001).

Table 3. Unit Root Results

\begin{tabular}{|c|c|c|c|}
\hline & & & \\
\hline Variable & $\mathrm{C}$ & C\&T & None \\
\hline $\mathrm{GDPC}_{\mathrm{t}}$ & -2.2542 & -2.2182 & -0.3443 \\
\hline $\mathrm{RD}_{\mathrm{t}}$ & $-3.3278 * *$ & $-3.3009^{*}$ & -1.0587 \\
\hline $\mathrm{ID}_{\mathrm{t}}$ & -2.2790 & -2.1949 & -1.3588 \\
\hline EMD $_{\mathrm{t}}$ & 1.5878 & -2.3440 & -1.6985 \\
\hline$\Delta \mathrm{GDPC}_{\mathrm{t}}$ & $-5.0784 * * *$ & $-5.0201 * * *$ & -5.1250 \\
\hline$\Delta \mathrm{EXD}_{\mathrm{t}}$ & $-5.7079 * * *$ & $-5.6389 * * *$ & $-5.6476 * * *$ \\
\hline$\Delta \mathrm{ID}_{\mathrm{t}}$ & $-6.6212 * * *$ & $-6.6154 * * *$ & $-6.6658 * * *$ \\
\hline$\Delta \mathrm{EMD}_{\mathrm{t}}$ & $-4.6734 * * *$ & $-4.6324 * * *$ & $-4.5767 * * *$ \\
\hline
\end{tabular}

Note: $\mathrm{C}$ and $\mathrm{T}$ represents intercept and trend respectively. $* * *$ shows are stationary at $1 \%$ level of significance. Source: Authors calculation

After investigating the unit root, we conduct the Bound test on the system of equations mentioned in equation 5 and results are reported in table 4. To validate the cointegration, we follow the critical F-values provided by Kripfganz and Schneider (2018) which are efficient in case of a small sample size. The bound testing results show that null hypotheses of no-cointegration $\delta_{11}=\delta_{12}=\delta_{13}=\delta_{14}=\delta_{15}=\delta_{16}=0 \quad$ and $\delta_{21}=\delta_{22}=\delta_{23}=\delta_{24}=\delta_{25}=\delta_{26}=0$ are rejected at $1 \%$ level of significance and cointegration is proved in these equations $\left(\mathrm{GDPC}_{\mathrm{t}} / \mathrm{PD}_{\mathrm{t}}, \mathrm{RD}_{\mathrm{t}}, \mathrm{EXD}_{\mathrm{t}}, \mathrm{ID}_{\mathrm{t}}, \mathrm{EMD}_{\mathrm{t}}\right)$ and $\left(\mathrm{PD}_{\mathrm{t}} / \mathrm{GDPC}_{\mathrm{t}}, \mathrm{RD}_{\mathrm{t}}, \mathrm{EXD}_{\mathrm{t}}, \mathrm{ID}_{\mathrm{t}}, \mathrm{EMD}_{\mathrm{t}}\right)$. For the rest equations, the null hypotheses $\delta_{31}=\delta_{32}=\delta_{33}=\delta_{34}=\delta_{35}=\delta_{36}=0, \quad \delta_{41}=\delta_{42}=\delta_{43}=\delta_{44}=\delta_{45}=\delta_{46}=0$, $\delta_{51}=\delta_{52}=\delta_{53}=\delta_{54}=\delta_{55}=\delta_{56}=0, \quad$ and $\quad \delta_{61}=\delta_{62}=\delta_{63}=\delta_{64}=\delta_{65}=\delta_{66}=0 \quad$ are not rejected and cointegration is not proved in the equations $\left(\mathrm{RD}_{\mathrm{t}} / \mathrm{GDPC}_{\mathrm{t}}, \mathrm{PD}_{\mathrm{t}}, \mathrm{EXD}_{\mathrm{t}}, \mathrm{ID}_{\mathrm{t}}, \mathrm{EMD}_{\mathrm{t}}\right),\left(\mathrm{EXD}_{\mathrm{t}} / \mathrm{GDPC}_{\mathrm{t}}, \mathrm{RD}_{\mathrm{t}}, \mathrm{PD}_{\mathrm{t}}, \mathrm{ID}_{\mathrm{t}}\right.$, $\left.\mathrm{EMD}_{\mathrm{t}}\right),\left(\mathrm{ID}_{\mathrm{t}} / \mathrm{GDPC}_{\mathrm{t}}, \mathrm{RD}_{\mathrm{t}}, \mathrm{EXD}_{\mathrm{t}}, \mathrm{PD}_{\mathrm{t}}, \mathrm{EMD}_{\mathrm{t}}\right)$, and $\left(\mathrm{EMD}_{\mathrm{t}} / \mathrm{GDPC}_{\mathrm{t}}, \mathrm{RD}_{\mathrm{t}}, \mathrm{EXD}_{\mathrm{t}}, \mathrm{ID}_{\mathrm{t}}, \mathrm{PD}_{\mathrm{t}}\right)$.

Table 4. Bound Test

\begin{tabular}{|l|l|}
\hline Model & F-value \\
\hline $\mathrm{F}\left(\mathrm{GDPC}_{\mathrm{t}} / \mathrm{PD}_{\mathrm{t}}, \mathrm{RD}_{\mathrm{t}}, \mathrm{EXD}_{\mathrm{t}}, \mathrm{ID}_{\mathrm{t}}, \mathrm{EMD}_{\mathrm{t}}\right)$ & $7.1269^{* * *}$ \\
\hline $\mathrm{F}\left(\mathrm{PD}_{\mathrm{t}} / \mathrm{GDPC}_{\mathrm{t}}, \mathrm{RD}_{\mathrm{t}}, \mathrm{EXD}_{\mathrm{t}}, \mathrm{ID}_{\mathrm{t}}, \mathrm{EMD}_{\mathrm{t}}\right)$ & $9.4874 * * *$ \\
\hline $\mathrm{F}\left(\mathrm{RD}_{\mathrm{t}} / \mathrm{GDPC}_{\mathrm{t}}, \mathrm{PD}_{\mathrm{t}}, \mathrm{EXD}_{\mathrm{t}}, \mathrm{ID}_{\mathrm{t}}, \mathrm{EMD}_{\mathrm{t}}\right)$ & 3.7353 \\
\hline $\mathrm{F}\left(\mathrm{EXD}_{\mathrm{t}} / \mathrm{GDPC}_{\mathrm{t}}, \mathrm{RD}_{\mathrm{t}}, \mathrm{PD}_{\mathrm{t}}, \mathrm{ID}_{\mathrm{t}}, \mathrm{EMD}_{\mathrm{t}}\right)$ & 2.4431 \\
\hline $\mathrm{F}\left(\mathrm{ID}_{\mathrm{t}} / \mathrm{GDPC}_{\mathrm{t}}, \mathrm{RD}_{\mathrm{t}}, \mathrm{EXD}_{\mathrm{t}}, \mathrm{PD}_{\mathrm{t}}, \mathrm{EMD}_{\mathrm{t}}\right)$ & 0.9018 \\
\hline $\mathrm{F}\left(\mathrm{EMD}_{\mathrm{t}} / \mathrm{GDPC}_{\mathrm{t}}, \mathrm{RD}_{\mathrm{t}}, \mathrm{EXD}_{\mathrm{t}}, \mathrm{ID}_{\mathrm{t}}, \mathrm{PD}_{\mathrm{t}}\right)$ & 2.5693 \\
\hline Kripfganz and Schneider $(2018)$ Critical Bound F-values & At $1 \% 2.8515-3.9571$ \\
& At 5\% 2.2611-3.2641 \\
& At $10 \% 1.9806-2.9266$ \\
\hline
\end{tabular}

Note: $\mathrm{C}$ and $\mathrm{T}$ represents intercept and trend respectively. $* * *$ shows are stationary at $1 \%$ level of significance. Source: Authors calculation 
Table 5 shows the long and short run results in a cointegration equation with a dependent variable GDPC $\mathrm{C}_{\mathrm{t}}$ The cointegration has already been confirmed for this equation in bound testing results presented in table 4 . It is further corroborated with a negative and statistically significant coefficient of error correction term. The diagnostic tests, in the bottom of table 5 and in the figure 1, also show that the results presented in table 5 are stable, reliable and consistent. In the long run, production concentration has positive and significant effect on the economic growth. $1 \%$ increase in the production concentration or $1 \%$ decrease in the production diversification is increasing the GDP per capita by $0.408 \%$. We conclude that increasing production concentration has pleasant economic growth effects. Table 1 showed that oil sector is carrying a significant proportion in the GDP. Therefore, we may conclude that increasing concentration of oil sector in GDP has positive economic growth effects. In the short run, the effect of production diversification is also found positive with relatively lesser elasticity than that of the long run. $1 \%$ increase in the production concentration in short run is increasing the GDP per capita by $0.1878 \%$.

Table 5. Long and Short Results: GDPC $t$ is dependent variable

\begin{tabular}{|c|c|c|c|c|}
\hline Variable & Coefficient & Std. Error & t-Statistic & Prob. \\
\hline \multicolumn{5}{|c|}{ Long Run } \\
\hline $\mathrm{PD}_{\mathrm{t}}$ & 0.4080 & 0.1268 & 3.2170 & 0.0030 \\
\hline $\mathrm{RD}_{\mathrm{t}}$ & 0.2927 & 0.1045 & 2.8012 & 0.0086 \\
\hline $\mathrm{EXD}_{\mathrm{t}}$ & -1.1651 & 0.5033 & -2.3148 & 0.0272 \\
\hline $\mathrm{ID}_{\mathrm{t}}$ & 0.0462 & 0.0993 & 0.4650 & 0.6451 \\
\hline $\mathrm{EMD}_{\mathrm{t}}$ & -0.4294 & 0.1619 & -2.6528 & 0.0123 \\
\hline Intercept & 11.6534 & 0.3419 & 34.0802 & 0.0000 \\
\hline \multicolumn{5}{|c|}{ Short Run } \\
\hline $\mathrm{GDPC}_{\mathrm{t}}$ & -0.2309 & 0.10789 & -2.1400 & 0.0401 \\
\hline $\mathrm{PD}_{\mathrm{t}}$ & 0.1878 & 0.0244 & 7.7104 & 0.0000 \\
\hline $\mathrm{RD}_{\mathrm{t}}$ & 0.0332 & 0.0134 & 2.4794 & 0.0186 \\
\hline $\mathrm{EXD}_{\mathrm{t}}$ & -0.1416 & 0.0725 & -1.9523 & 0.0597 \\
\hline $\mathrm{EXD}_{\mathrm{t}-1}$ & 0.2458 & 0.0561 & 4.3834 & 0.0001 \\
\hline $\mathrm{ID}_{\mathrm{t}}$ & -0.0255 & 0.0144 & -1.7643 & 0.0872 \\
\hline $\mathrm{ID}_{\mathrm{t}-1}$ & -0.0438 & 0.0148 & -2.9654 & 0.0057 \\
\hline $\mathrm{EMD}_{\mathrm{t}}$ & 0.0748 & 0.0290 & 2.5837 & 0.0145 \\
\hline $\mathrm{ECT}_{\mathrm{t}-1}$ & -0.2128 & 0.0276 & -7.6969 & 0.0000 \\
\hline \multicolumn{5}{|c|}{ Diagnostic Tests } \\
\hline Heteroscedasticity & \multicolumn{3}{|c|}{ F-value $=1.3572$} & 0.2302 \\
\hline Serial Correlation & \multicolumn{3}{|c|}{ F-value $=0.8639$} & 0.4317 \\
\hline Normality & \multicolumn{3}{|c|}{ Chi-square $=0.6155$} & 0.7351 \\
\hline
\end{tabular}




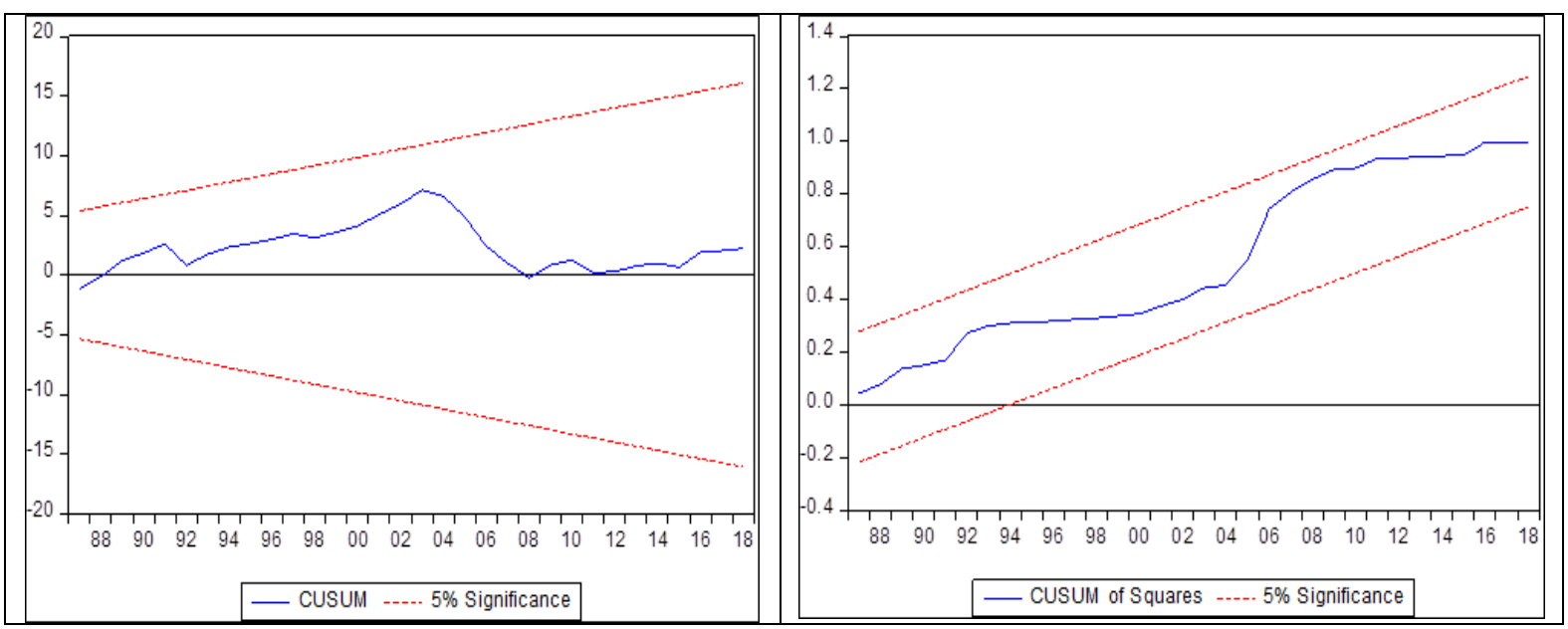

Figure 1. CUSUM and CUSUMsq Tests

The effect of $\mathrm{RD}_{\mathrm{t}}$, government revenue concentration, has positive and significant effect on the GDP per capita in the long run. $1 \%$ increase in the revenue concentration or $1 \%$ decrease in the revenue diversification is found helpful in increasing GDP per capita by $0.2927 \%$. Government revenues are sole source to invest in the infrastructure of an economy to support the economic activities and economic growth of a country. Saudi Arabia is low tax based economy and oil sector is majorly contributing to its government revenues. Hence, oil sector concentration in the government revenues is not found bad for the economic growth but is found supportive to the economic growth phenomenon. The effect of revenue concentration is also found positive on the GDP per capita in the short run with a minute elasticity. $1 \%$ increase in the revenue concentration in the short run is increasing the GDP per capita by $0.0332 \%$.

The effect of EXD more than 1 . Therefore, $1 \%$ increase in the exports concentration or $1 \%$ decrease in the exports diversification is depressing the GDP per capita by $1.1651 \%$. Exports of Saudi Arabia are heavily concentrated by oil sector and oil exports are depending on the world oil prices which are highly volatile. Hence, the oil exports are highly volatile because of fluctuation of world oil prices now-a-days. Therefore, we conclude that a high concentration of oil exports in the total exports is responsible for depressing the economic growth in the Kingdom. Moreover, the elasticity coefficients suggest that negative elasticity of export concentration is higher than some of positive elasticities of production and revenue concentration. Therefore, the overall effects of oil sector concentration in the production, revenue and exports may be claimed negative for the economic growth of the Kingdom. Moreover, the effect of export concentration on GDP per capita is also found negative in the short run with a low elasticity with compare to long run elasticity and its lag effects is showing a positive growth effect. The effect of investment concentration is found statistically insignificant in the long run. This insignificant effect can be justified by a reason that investment in private sector is found higher than oil and government sectors but the proportion of private sector in GDP is mostly found lesser than proportion of private sector investment in the total investment. In the short run, the effects of investment concentration and its lag are negative on the GDP per capita. It can be concluded that investment concentration has negative growth effect in the short run.

In last, the effect of employment concentration is found negative on the GDP per capita. $1 \%$ increase in the employment concentration or 1\% decrease in employment diversification is decreasing the GDP per capita by $0.4294 \%$ in the long run. Employment index is developed by the share of employment in public and private sectors. The proportion of private sector is always found more than public sector but public sector has contributed a significant proportion of employment during 1970-1999. Due to a significant employment share of public sector, the employment concentration is found responsible for depressing economic growth because productivity 


\section{ENTREPRENEURSHIP AND SUSTAINABILITY ISSUES}

ISSN 2345-0282 (online) http://jssidoi.org/jesi/

2020 Volume 7 Number 4 (June)

http://doi.org/10.9770/jesi.2020.7.4(52)

of public sector employees may usually be assumed lesser than the private sector. Unlike to long run effect, the short run effect of employment concentration is found positive on the GDP per capita.

Table 6. VECM based Granger causality results

\begin{tabular}{|l|l|l|l|l|l|l|l|}
\hline Variable & $\Delta \mathrm{GDPC}_{\mathrm{t}-1}$ & $\Delta \mathrm{PD}_{\mathrm{t}-1}$ & $\Delta \mathrm{RD}_{\mathrm{t}-1}$ & $\Delta \mathrm{EXD}_{\mathrm{t}-1}$ & $\Delta \mathrm{ID}_{\mathrm{t}-1}$ & $\Delta \mathrm{EMD}_{\mathrm{t}-1}$ & $\mathrm{ECM}_{\mathrm{t}-1}$ \\
\hline$\Delta \mathrm{GDPC}_{\mathrm{t}}$ & & 8.2608 & 4.0375 & 0.2986 & 0.7413 & 4.0076 & 21.9507 \\
& & $(0.0161)$ & $(0.1328)$ & $(0.8613)$ & $(0.6903)$ & $(0.1348)$ & $(0.0154)$ \\
\hline$\Delta \mathrm{PD}_{\mathrm{t}}$ & 4.1527 & & 8.0494 & 6.8502 & 0.3363 & 0.9921 & 21.3035 \\
& $(0.1254)$ & & $(0.0179)$ & $(0.0325)$ & $(0.8452)$ & $(0.6089)$ & $(0.0191)$ \\
\hline$\Delta \mathrm{RD}_{\mathrm{t}}$ & 1.6799 & 1.5422 & & 1.0667 & 1.1584 & 1.3107 & 5.6353 \\
& $(0.4317)$ & $(0.4625)$ & & $(0.5866)$ & $(0.5604)$ & $(0.5193)$ & $(0.8449)$ \\
\hline$\Delta \mathrm{EXD}_{\mathrm{t}}$ & 0.4308 & 1.3018 & 0.2086 & & 4.7807 & 2.0073 & 10.6689 \\
& $(0.8062)$ & $(0.5216)$ & $(0.9010)$ & & $(0.0916)$ & $(0.3665)$ & $(0.3839)$ \\
\hline$\Delta \mathrm{ID}_{\mathrm{t}}$ & 0.4827 & 0.4981 & 0.9957 & 1.7349 & & 0.8625 & 3.6147 \\
& $(0.7856)$ & $(0.7795)$ & $(0.6078)$ & $(0.4200)$ & & $(0.6497)$ & $(0.9631)$ \\
\hline$\Delta \mathrm{EMD}_{\mathrm{t}}$ & 0.8527 & 12.6972 & 4.6806 & 4.4645 & 8.4316 & & 38.3834 \\
& $(0.6529)$ & $(0.0017)$ & $(0.0963)$ & $(0.1073)$ & $(0.0148)$ & & $(0.0000)$ \\
\hline
\end{tabular}

In the causality analyses presented in table 6, production concentration is causing to the GDP per capita. Further, government revenue and exports concentrations are causing to the production concentration. These concentration indices are largely influenced by oil sector and have indirect effect on the economic growth through the production concentration. The investment concentration is causing to the export concentration. Lastly, the production, investment and revenue concentrations are causing to the employment concentration.

\section{Conclusions and Implications}

Saudi Arabia is largest oil exporter in the world market and her most of macroeconomic performance is heavily depending on the oil sector. This present research calculates the production, exports, government revenue, investment and employment concentration indices in Saudi Arabia using normalized Herfindahl Hirschman Index and discusses the level of concentration or diversification in each calculated macroeconomic domain. We utilize a maximum available time range of 1970-2018 for oil and non-oil contribution in the production, exports, government revenue and investment. We apply the unit root test on the series to test the level of integration, ARDL Bound testing approach to find the cointegration among the hypothesized models and Granger Causality test to find the direction of relationships. We find that level of concentration is very high in the exports and government revenues in most of development plan periods. Moreover, we also find that public sector employment has significantly high in the period 1970-1999. In the regression analysis, we find that production and government revenue concentrations have positive effect on the economic growth of the Kingdom in both long and short run. The production concentration is majorly observed due to the oil sector. Therefore, the oil sector concentration is helpful in accelerating the economic growth. And, the government revenue is also majorly concentrated by the oil sector and oil concentration in government revenue is found helpful for achieving higher economic growth. The export concentration has negative effects on the economic growth both in long and short run. The export sector is heavily concentrated by oil exports and this oil export dependency is found harmful for the economic growth of the Kingdom. From the estimated elasticities, we find that negative growth effect of exports concentration is found larger than the cumulated positive growth effects of production and revenue concentrations. Therefore, we conclude that oil sector concentration in the economy of Saudi Arabia is overall harmful to the sustainability of economic growth of the Kingdom. The investment concentration has statistically insignificant effect in the long run but has negative effect on the economic growth in the short run. Investment is mostly concentrated by public and private non-oil sectors' investment and its insignificant effect realizes the fact and income is mostly contributed by oil sector even with lesser proportion of investment in the oil sector. Lastly, the public sector employment carries a significant share in the total employment and employment concentration has negative effect 


\section{ENTREPRENEURSHIP AND SUSTAINABILITY ISSUES}

ISSN 2345-0282 (online) http://jssidoi.org/jesi/

2020 Volume 7 Number 4 (June)

http://doi.org/10.9770/jesi.2020.7.4(52)

on the economic growth in the long run. The Granger Causality test reveals the unidirectional causality from production concentration to the economic growth and unidirectional causality is also found from government revenue and exports concentrations to the production concentration. Though, these concentrations have also indirect effects on the economic growth through production concentration. Further, investment concentration is causing to the export concentration, and production, investment and revenue concentrations are causing to the employment concentration as well.

The results show that production and revenue concentrations by oil sector have positive effect on the economic growth and government has targeted production and revenue diversification policy in the Vision 2030. Therefore, production and government revenue diversification policies should be traced carefully without harming the economic growth of the Kingdom. The exports concentrated by oil sector have more than proportionate negative effect on the economic growth. Hence, non-oil exports sector should have government support to reduce the negative growth effects of oil exports. At first, public sector is sufficiently large in the Kingdom and it can focus the non-oil export promotion. Secondly, tax rebates and other government support should be provided to private sector for the promotion of non-oil exports. The government revenue concentrated by oil sector has positive effect on the economic growth, which is good in the oil prices boom days, but may have adverse effect during oil price crisis period. Now-a-days, the world is facing the lower oil prices and it may have a long term adverse consequences on the government reserve and on the economic growth consequently. Therefore, the non-tax based economy should be shifted to the tax base so government spending capacity should not be affected to support the economic growth sustainability in the times of oil price crisis. The investment is concentrated by public and private non-oil sectors and has statistically insignificant effects on the economic growth. Hence, non-oil sector investment seems less productive and government should provide the advisory services to the private investors to invest in more productive channels to support the economic growth of the Kingdom. Lastly, the employment has a significant share from public sector and has negative effect on the growth. Government should trace the educational and incentive policies to raise the private sector employment which is assumed more productive than that of public sector employment to support the economic growth of the Kingdom.

\section{Funding Acknowledgement}

The authors extend their appreciation to the Deputyship for Research \& Innovation, Ministry of Education in Saudi Arabia for funding this research work through the project number (DRI-KSU-SS-341).

\section{References}

Adelaja, A.O., Akaeze, H.O. (2018). Supply response, economic diversification and recovery strategy in the oil sector. Energy Strategy Reviews 21: 111-120. https://doi.org/10.1016/j.esr.2018.05.002

Aker, S.L., Aghaei, I. (2019). Comparison of Business Environments in Oil-Rich MENA Countries: A Clustering Analysis of Economic Diversification and Performance. Emerging Markets Finance and Trade 55(12): 2871-2885. https://doi.org/10.1080/1540496X.2018.1537185

Al Bakr, A. (2015). Challenges to production base diversification in Saudi Arabia. SAMA Working Paper No. WP/15/8, Economic Research Department, Saudi Arabian Monetary Agency, Riyadh. http://www.sama.gov.sa/ar-sa/EconomicResearch/WorkingPapers

Albassam, B. (2015). Economic diversification in Saudi Arabia: myth or reality? Resources Policy 44: $112-117$. https://doi.org/10.1016/j.resourpol.2015.02.005

Ali, M., Memon, M.H. (2019). Economic Diversification and Human Development in South Asia. Journal of Asian and African Studies 54(5): 674-690. https://doi.org/10.1177/0021909619836133 


\section{ENTREPRENEURSHIP AND SUSTAINABILITY ISSUES}

ISSN 2345-0282 (online) http://jssidoi.org/jesi/

2020 Volume 7 Number 4 (June)

http://doi.org/10.9770/jesi.2020.7.4(52)

Al-Khatib, M.A. (2011). The impact of economic diversification on the non-oil sector. King Saud Journal 18(2): 203-231. https://cba.ksu.edu.sa/sites/cba.ksu.edu.sa/files/attach/Arab\%20Journal\%20of\%20Adminsitrative\%20Science.pdf

Al-Khatib, M.P. (2014). Diversification and growth in the Saudi economy. The first conference for colleges of business administration in the universities of the Gulf Cooperation Council states. Riyadh. https://fac.ksu.edu.sa/khatibm/publication/111117

Alley, I. (2018). Oil price and USD-Naira exchange rate crash: Can economic diversification save the Naira? Energy Policy 118: 245-256. https://doi.org/10.1016/j.enpol.2018.03.071

Al-Tit, A.A., Omri, A. (2018). The post-oil era in Saudi Arabia: the rationale for economic diversification. Journal of the Islamic University for Economic and Administrative Studies 26(3): 57-73. https://journals.iugaza.edu.ps/index.php/IUGJEB/article/view/3917

Basile, R., Parteka, A., Pittiglio, R. (2018). Export diversification and economic development: A dynamic spatial data analysis. Review of International Economics 26(3): 634-650. https://doi.org/10.1111/roie.12316

Cai, Y., Normann, R.B, Pinheiro, R.C., Sotarauta, M. (2018). Economic specialization and diversification at the country and regional level: introducing a conceptual framework to study innovation policy logics. European Planning Studies 26(12): 2407-2426. https://doi.org/10.1080/09654313.2018.1529142

del Rosal, I. (2019). Export diversification and export performance by destination country. Bulletin of Economic Research 71(1): 58-74. https://doi.org/10.1111/boer.12181

Dickey, D.A., Fuller, W.A. (1981). Likelihood Ratio Statistics for Autoregressive Time Series with Unit Root. Econometrica 49: 10571072. https://www.jstor.org/stable/1912517

Ghanem, P.M., Fawaz M.M. (1998). An economic study of the factors determining the allocation of economic and agricultural resources in the light of the structural change of the Egyptian economy. Annals of Agricultural Sciences 2: 505-537. https://www.amf.org.ae/sites/default/files/Research\%20and\%20Studies/AMF\%20Economic\%20Papers/ar/Performance\%20and\%20Source s.pdf

Hirschman, A. (1964). The Paternity of an Index. American Economic Review 54(4-6): 761-762. https://www.jstor.org/stable/1818582

Jawadia, F., Ftiti, Z. (2019). Oil price collapse and challenges to economic transformation of Saudi Arabia: A time-series analysis. Energy Economics 80: 12-19. https://doi.org/10.1016/i.eneco.2018.12.003

Ji, T., Mei, D. (2019). Export Diversification and Fiscal Procyclicality. Emerging Markets Finance and Trade, https://doi.org/10.1080/1540496X.2019.1589446

Kripfganz, S., Schneider, D.C. (2018). Response surface regressions for critical value bounds and approximate p-values in equilibrium correction models. Manuscript, University of Exeter and Max Planck Institute for Demographic Research. www.kripfganz.de

Lapteacru, I. (2012). Assessing Lending Market Concentration in Bulgaria: The Application of a New measure of Concentration. The Journal of Comparative Economics 9(1): 79-102. https://ideas.repec.org/a/liu/liucej/v9y2012i1p79-102.html

Liu, Y., Mauer, D.C., Zhang, Y. (2018). The hedging benefits of industrial and global diversification: Evidence from economic downturns. Journal of Business Finance and Accounting 45(9-10): 1322-1351. https://doi.org/10.1111/jbfa.12354

Maalel, N., Mahmood, H. (2018). Oil-Abundance and Macroeconomic Performance in the GCC Countries. International Journal of Energy Economics and Policy 8(2): 182-187. https://www.econjournals.com/index.php/ijeep/article/view/6010

Masood, O., Tvaronavičienė, M., Javaria, K. (2019). Impact of oil prices on stock return: evidence from G7 countries. Insights into Regional Development 1(2): 129-137. https://doi.org/10.9770/ird.2019.1.2(4)

Merzuk, P.T. (2013). Economic diversification in the Arab Gulf countries, an approach to the rules and evidence. Gulf Economic Magazine 24: 5- 53. https://www.iasj.net/iasj?func=fulltext\&aId=78673

Nisar, S., Peng, K., Wang, S., Ashraf, B.N. (2018). The technical efficiency of South Asian commercial banks and the effects of income diversification. International Journal of Information and Management Sciences 29(3): 279-302. https://doi.org/10.6186/IJIMS.201809$\underline{29(3) .0003}$ 
ENTREPRENEURSHIP AND SUSTAINABILITY ISSUES

ISSN 2345-0282 (online) http://jssidoi.org/jesi/

2020 Volume 7 Number 4 (June)

http://doi.org/10.9770/jesi.2020.7.4(52)

Pesaran, M.H., Shin, Y., Smith, R.J. (2001). Structural analysis of vector error correction models with exogenous I(1) variables. Journal of Econometrics 97(2): 293-343. https://doi.org/10.1016/S0304-4076(99)00073-1

Saudi Arabian Monetary Agency (2019). Annual statistics 2019. Government of Saudi Arabia, Riyadh, Saudi Arabia. http://www.sama.gov.sa/en-US/EconomicReports/Pages/YearlyStatistics.aspx

Appendix: Data utilized

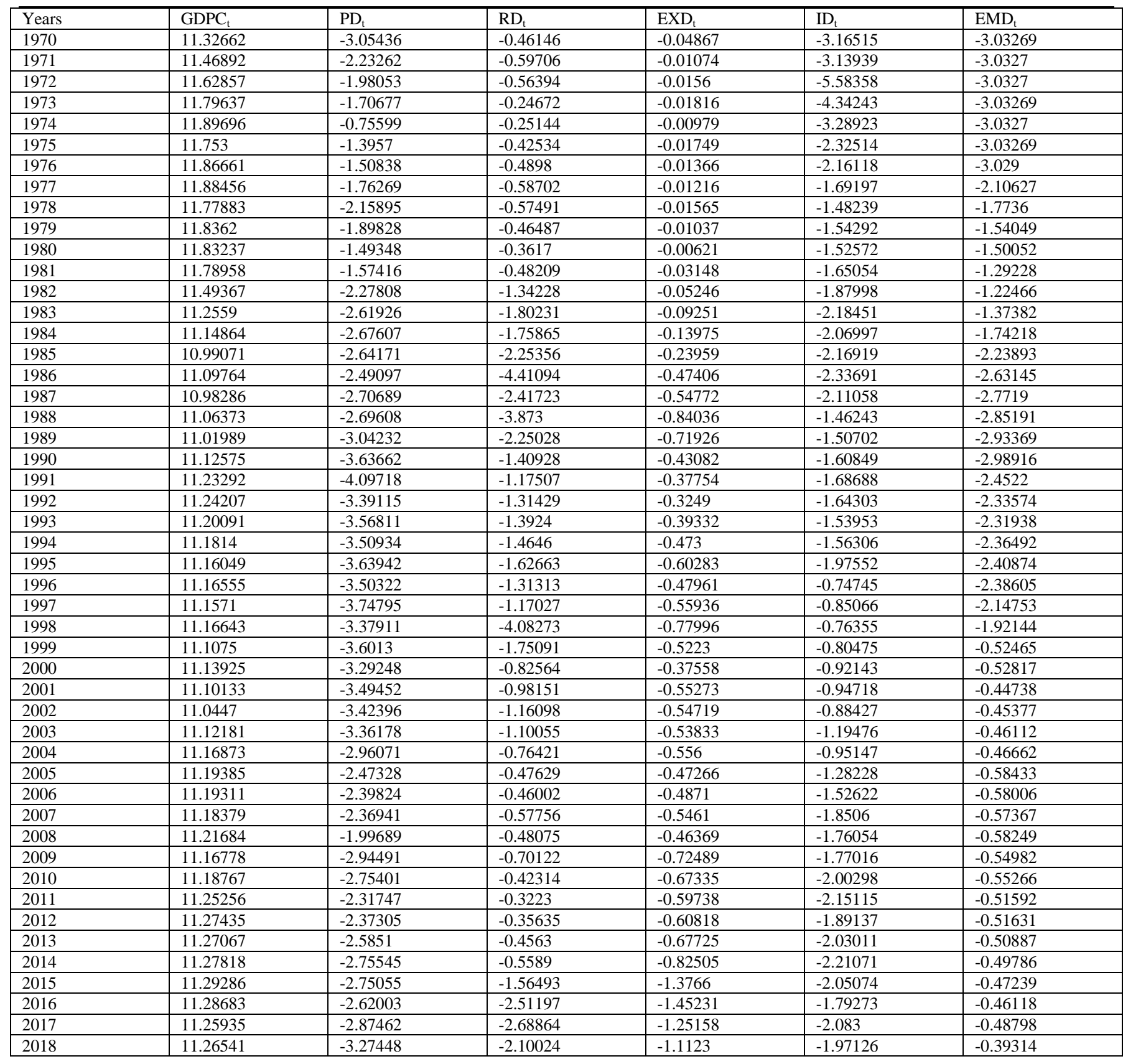


Khalid Abdullah ALKHATHLAN

ORCID ID: https://orcid.org/0000-0001-5643-5570

Tarek Tawfik Yousef ALKHATEEB

ORCID ID: https://orcid.org/0000-0001-8215-9522

Haider MAHMOOD

ORCID ID: https://orcid.org/0000-0002-6474-4338

Wardah Abdulrahman BINDABEL

ORCID ID: https://orcid.org/0000-0002-0039-1019 